\title{
Factor Branding in Selection of Higher Educational Institutions in India
}

\author{
Dr.S.Franklin John ${ }^{1}$, Ms.S.Senith ${ }^{2}$ \\ ${ }^{I}$ (Principal and Professor, Nehru College of Management/ Bharathiar University, India) \\ ${ }^{2}$ (Assistant Professor, Nehru College of Management/ Bharathiar University, India)
}

\begin{abstract}
The study was designed to investigate the influence of Branding in higher Educational Institutions. The questionnaires were given to 26 engineering institutions with existence of at least ten years anonymity for all respondents and institutions was guaranteed. Reports of the study were promised to each participating institution, but respondents and institutional names were kept confidential. Respondents to the questionnaire were only students. Out of 1000 students contacted, 780 questionnaires were received with required coverage and details. The participants completed the two sets of self-reported questionnaires, including Background characteristics and variables chosen for this study in order to measure the influence of branding in Engineering Institutions and the Service,Innovation, Quality, Price, Image and External Exposure. The collected data were computed and analysed using multiple regressions and Partial least Squares. The findings of the study were generalized as follows: Statistically significant differences were found in Brand rating by the different brand dimensions like Service, Innovation, Quality, Price,Image and External Exposure. In the end of the study implications and conclusion were provided.
\end{abstract}

Keywords - brand, Education, External Exposure, Influence, Service

\section{Introduction}

India was a very backward country before independence. Mostly cottage based industry was in it. To fulfil the interests of British imperialism Britishers developed few modern industries in India. This trade was mostly apprehensive with extraction of minerals, transport system and agriculture. The industrial policy of the British government was based on the interests of British Capitalist Class. India was treated as a marketplace for exporting raw materials (both agricultural and mineral) to England and importing many manufactured goods from England to India. In this way, the Britishers demoralized the Indian economy. As far as education was concerned only $7 \%$ of the population was educated when India became free. This rate of literacy was somewhat hopeless in itself. If we take engineering education into contemplation this figure becomes all the more miserable. Kumar(2011)

East India Company felt the require meant for some workers and technicians for their own interests. It leads to the establishment of Roorkee Institution in 1847. The first government college of 153 engineering was established in 1854 in Poona, the second 'Bengal Engineering College' in Howrah (1856) and the third 'Guindy Engineering College' in Madras (1862). The Pune Engineering College was setup in 1886. Besides these colleges another Institute 'Victoria Jubilee Technical Institute' was established in 1887 in Bombay with Electrical, Mechanical and Textile engineering and technology trades.

To meet the need larger number of good institutions of Engineering and technology, private initiative have an important role to provide opportunities for technical education to a larger number of students. Amir Kumar (2011)

Throughout the business world, branding is well thought-out the groundwork of marketing. It is as a result an inseparable component of business strategy. When placed into context, branding is much more than putting a fancy name on a product. Brands represent grouped combinations of attributes, communicated through carefully selected names or symbols, which influence the perceptions of targeted groups to create value. The value of a brand resides in its effectiveness and its ability to deliver the required message of the promise that the product or service will deliver to the target audience. Sari Kalin (2006)

Brands are the aggregate of all the imagery that people have in their heads about a particular company or a program. Therefore, branding is deeply seated in the psycho-sociology aspects of the target group. The focus of this paper is to know the influence of branding in engineering institutions. 


\section{II . Review of Literature}

Kapferer (1997) mentioned that "the brand is a sign -therefore external- whose function is to reveal the unknown qualities of the product which are inaccessible to contact" (p. 28). The brand served to recognize a product and to make a distinction it from the competition. Regarding the brand management process as related to the function of a brand as an identifier, Aaker and Joachmisthaler (2000) discuss the conventional branding model where a brand management team was responsible for creating and coordinating the brand's management program. In this location, the brand manager was not high in the company's hierarchy; his focus was the shortterm financial results of single brands and single products in single markets. According to Keller (2003a), brand awareness consists of brand recognition -the "consumer's ability to confirm previous exposure to the brand when given a brand as a cue" (p. 67)- and brand recall -the "consumer's ability to retrieve the brand form memory when given the product category, the needs fulfilled by the category, or a purchase or usage situation as cue" (p. 67). On the other hand, "brand image is created by marketing programs that link strong, favourable, and unique associations to the brand in the memory" (p. 70)

\subsection{OBJECTIVES OF THE STUDY}

\section{Research Methodology}

1) To find out the influence of Branding in Engineering Institutions.

\subsection{HYPOTHESES}

Following are the test Hypothesis proposed for the research study. These hypotheses will help us to understand the Educational brand.

$\mathrm{H}_{1}$ : Brand rating is influenced by the different dimensions of Educational brand.

The sub hypotheses were:

$\mathrm{H}_{1 \mathrm{a}}$ : Service is influencing Brand rating

$\mathrm{H}_{1 \mathrm{~b}}$ : Innovation is influencing Brand rating

$\mathrm{H}_{1 \mathrm{c}}$ : Quality is influencing brand rating

$\mathrm{H}_{1 \mathrm{~d}}$ : Price is influencing Brand rating

$\mathrm{H}_{1 \mathrm{e}}$ : Image is influencing Brand rating

$\mathrm{H}_{1 \mathrm{f}}$ : External Exposure is influencing Brand rating

\subsection{RESPONDENT SAMPLE}

The questionnaires were given to 26 engineering institutions with existence of at least ten years anonymity for all respondents and institutions was guaranteed. Reports of the study were promised to each participating institution, but respondents and institutional names were kept confidential. Respondents to the questionnaire were only students. Out of 1000 students contacted, 780 questionnaires were received with required coverage and details.

\subsection{DESIGN OF SAMPLING FRAMEWORK}

Descriptive design is formed to be more suitable to carry out the study. As the universe consists of different categories of institutions such as Government institutions, Government aided institutions, Self financing institutions and Deemed Universities. They were taken as separate strata to represent the universe. Stratified random sampling method was used. The respondents were selected from the AICTE and UGC Website.

\subsection{JURY OPINION INTERVIEWS DERIVE DIMENSIONS}

An exclusive jury opinion was sought from 10 educational administrators (VC's / Principals) of the engineering institutions from various parts of Tamilnadu along with 4 faculty members were interviewed. One chancellor of a Deemed university, two student representatives of engineering institutions, one dean of student affairs and academic affairs and three department heads were required to respond the following questions:

1) What are all the factors that influence students while choosing an educational institution for their higher education?

2) What are all the factors that can support to pursue a strong Brand for higher educational institutions?

3) In the dimensions generated from the literature, which ones are not relevant to the Branding of Higher Educational Institutions?

4) What are all the sources from where the students get informations on higher educational institutions?

5) What are all the factors which are taken in to consideration by the rating agencies while ranking the higher educational institutions?

6) What are all the attributes of educational Brand? 
Interviews tasked from one to four hours and special emphasis was placed on criteria related to the factors influencing Educational Brand and the various factors which students expects from an engineering institution while choosing an engineering college/ university for their higher education. Some of the dimensions regulating from the interviews did relate to aggregate of individuals and the focus tended to be on the entire institution rather than on one institutional submit. As Campbell (2002) stated "Criterion combination quite properly is based on value judgments and there is no algorithm or higher order truth to which we can appeal". Several alternate groupings were tried but the one used here represents the only grouping for attributes of educational brand generated from the interviews. These six dimensions represented conceptually different constructs although they were not assumed to be independent. These dimensions were selected of lithe careful examination of the reviews after matching with the strategic options suggested by various strategy experts like porter, Arsoff and Chander.

\subsection{INSTRUMENTS}

For the purpose of studying the objectives, a structured questionnaire was developed to collect data on the research variables. The questionnaire had two parts: the first section of the instrument consisted of forcedchoice questions about demographic characteristics: name, gender, address, type of the institution and average annual income. The variables chosen for this study in order to measure the influence of branding in Higher Educational Institutions are the Price, Service, Innovation, Quality, Image and External exposure.

\subsection{RELIABILITY ANALYSIS}

The data collected from the pilot study was subjected to reliability test using Cronbach Alpha. Traditionally, the Cronbach $\alpha$ coefficient (Cronbach, 1951) has been used to evaluate reliability. The reliability analysis of the Educational Branding Instrument was computed by using Alpha technique. The analysis was done for all the six dimensions of the educational Brand to establish the level of reliability in the overall study. In the same way the reliability analysis was carried out to the factors determining .The reliability coefficients for the variables chosen for the study should have to be more than 0.70, to consider it as an acceptable value (Nunally, 1978). In this study the Reliability analysis shows that all the factors have shown alpha value greater than 0.7 , indicating the evidence of reliability and the over all reliability of the instrument is 0.82 . So, the items constituting each variable under study have reasonable internal consistency and shows that all the dimensions of Educational Branding have a positive reliability. The factors and dimensions included for analysis carry a good degree of reliability to support the objectives formulated. All dimensions have got significant relationship to make the real representation of the study. Hence it is concluded that the data collected in this study is highly reliable.

\section{Data Analysis}

The Statistical Package for the Social Science (SPSS) for Microsoft Windows 20.0 was used to complete the analysis of the collected data.

Multiple regression is used in this study to analyze the dataset. The general purpose of multiple regression (the term was first used by Pearson, 1908) is to learn more about the relationship between several independent or predictor variables and a dependent or criterion variable. Multiple regression is a statistical technique that allows us to predict someone's score on one variable on the basis of their scores on several other variables.

Partial Least Squares Regression is also computed which is an important step in PLS path modeling, a multivariate data analysis technique that employs latent variables. Partial least squares regression (PLSregression) bears some relation to principal component analysis; instead of finding the hyper planes of minimum variance, it finds a linear model describing some predicted variables in terms of other observable variables. It is used to find the fundamental relations between two matrices ( $\mathrm{X}$ and $\mathrm{Y}$ ), i.e. a latent variable approach to modeling the covariance structures in these two spaces. A PLS model will try to find the multidimensional direction in the $\mathrm{X}$ space that explains the maximum multidimensional variance direction in the $\mathrm{Y}$ space.

\section{RESULT OF DATA ANALYSIS}

To analyze the relationship between branding dimensions and brand rating.

"Branding of Higher Educational Institutions" is influenced by Service, Innovation, Quality, price, Image and External Exposure. Hence, regression equation can formed as,

$$
\mathrm{Y}=\mathrm{X} 1 \beta 1+\mathrm{X} 2 \beta 2+\mathrm{X} 3 \beta 3+\mathrm{X} 4 \beta 4+\mathrm{X} 5 \beta 5+\mathrm{X} 6 \beta 6+\mathrm{C}
$$

Branding $=$ service $\beta 1+$ Innovation $\beta 2+$ Quality $\beta 3+$ Price $\beta 4+$ Image $\beta 5+$ External exposure $\beta 6+C$ To test the above model we performed multiple regression in SPSS. For the analysis we have taken brand rating as dependent factor and factors like service, innovation, quality, image, price and external exposure are independent factors. Brand ranking of the institution is measured in a ten point scale and all other independent 
factors and their factor scores obtained in factor analysis is taken for the study. By analysing we got the following tables.

Table 1 : Model Summary

\begin{tabular}{|l|l|l|l|l|l|}
\hline Model & $\mathbf{R}$ & R Square & $\begin{array}{l}\text { Adjusted } \\
\text { Square }\end{array}$ & $\begin{array}{l}\text { Std. Error of the } \\
\text { Estimate }\end{array}$ \\
\hline 1 & $.945^{\mathrm{a}}$ & .892 & .892 & .201 \\
\hline
\end{tabular}

a. Predictors: (constant), Factor score of External Exposure, Factor score of Image, Factor score of price, factor score of quality, factor score of innovation, factor score of service.

From the above table the $\mathrm{R}$ square value is .892 and adjusted $\mathrm{R}$ square value is .892 and this tells us that our model account for $89.2 \%$ of varience in the influence of educational brand study. This is the clear indication that this model is a very good model .

Table 2 : ANOVA

\begin{tabular}{|l|l|l|l|l|l|}
\hline Model & $\begin{array}{l}\text { Sum of } \\
\text { Squares }\end{array}$ & Df & $\begin{array}{l}\text { Mean } \\
\text { Square }\end{array}$ & F & Sig. \\
\hline Regression & 258.996 & 6 & 43.166 & 1068.762 & $.000^{\mathrm{a}}$ \\
\hline Residual & 31.221 & 773 & .040 & & \\
\hline Total & 290.216 & 779 & & & \\
\hline
\end{tabular}

a. Predictors: (constant), Factor score of External Exposure, Factor score of Image, Factor score of price, factor score of quality, factor score of innovation, factor score of service.

b. Dependent Variable: Brand Rating of the Institution of the students

From the above ANOVA table it is inferred that the F value is 1068.762 and the significance is .000 . As the significance is less than .05 . It clearly reveals the fact that the model which we have taken for study is statistically significant.

Table 3: Coefficients

\begin{tabular}{|c|c|c|c|c|c|}
\hline \multirow{2}{*}{ Model } & \multicolumn{2}{|c|}{$\begin{array}{l}\text { Unstandardized } \\
\text { Coefficients }\end{array}$} & \multirow{2}{*}{$\begin{array}{l}\text { Standardized } \\
\text { Coeff }\end{array}$} & \multirow{2}{*}{$\mathbf{T}$} & \multirow{2}{*}{ Sig } \\
\hline & B & $\begin{array}{l}\text { Std. } \\
\text { Error }\end{array}$ & & & \\
\hline 1 (Constant) & 4.443 & .007 & & 616.005 & .000 \\
\hline Factor score of Service & .112 & .007 & .184 & 15.613 & .000 \\
\hline Factor score of innovation & 631E-02 & .007 & .043 & 3.656 & .000 \\
\hline Factor score of Quality & 715E-02 & .007 & .077 & 6.548 & .000 \\
\hline Factor score of Price & .136 & .007 & .223 & 18.941 & .000 \\
\hline Factor score of Image & $863 \mathrm{E}-02$ & .007 & .162 & 13.698 & .000 \\
\hline Factor Score of Ext Exposure & .537 & .007 & .880 & 74.607 & .000 \\
\hline
\end{tabular}

a. Dependent Variable : Brand Rating of the Institution of the students

The above standardised beta coefficient table give a measure of contribution of each variable to the model. $\mathrm{T}$ value of service is 15.613 and significance is .00 and the probability is less than .05 . Thus, service is influencing in prediction of over all brand rating of the education institution. T value of Innovation is 3.654 and significance is .00 and the probability is less than .05 . Hence, innovation is influencing in prediction of over all brand rating of the education institution. T value of Quality is 6.548 and significance is .00 and the probability is less than .05. Quality is influencing in prediction of over all brand rating of the education institution. T value of Price is 18.941 with significance of .00 and the probability is less than .05 . Hence, price is influencing in prediction of over all brand rating of the education institution. T value of Image is 13.698 and significance is .00 and the probability is less than .05 . Hence, image is influencing in prediction of over all brand rating of the education institution. T value of External Exposure is 74.607 and significance is .00 and the probability is less than .05 . Hence, external exposure is influencing in prediction of over all brand rating of the education institution.

From the above beta values the Branding equation can redrafted as

Branding $=$ Service $\beta 1+$ Innovation $\beta 2+$ Quality $\beta 3+$ Price $\beta 4+$ Image $\beta 5+\quad$ External exposure $\beta 6$

Branding $=(.184)$ Service $+(.043)$ Innovation $+(.077)$ Quality $+(.223)$ Price $+(.162)$ Image $+(.880)$ External Exposure

Partial Least Squares 
Partial Least Squares (PLS) regression is a multivariate data analysis technique which can be used to relate several response $(\mathrm{Y})$ variables to several explanatory $(\mathrm{X})$ variables. The method aims to identify the underlying factors, or linear combination of the $\mathrm{X}$ variables, which best model the $\mathrm{Y}$ dependent variables. As the distribution of PLS is unknown, conventional significance testing is impossible. However, testing may be accomplished by bootstrap methods such as the jacknife, as illustrated by Davies (2001).

Table 4 Structural Model-Bootstrap

\begin{tabular}{|l|c|c|c|c|}
\hline & $\begin{array}{c}\text { Entire Sample } \\
\text { Estimate }\end{array}$ & $\begin{array}{c}\text { Mean of Sub } \\
\text { Samples }\end{array}$ & $\begin{array}{c}\text { Standard } \\
\text { error }\end{array}$ & T-Statistic \\
\hline External Exposure->Branding & 0.7550 & 0.7588 & 0.0183 & 41.2585 \\
\hline Service->Branding & 0.2170 & 0.2173 & 0.0248 & 8.7474 \\
\hline Innovation->Branding & 0.0260 & 0.0304 & 0.0151 & 2.7252 \\
\hline Quality->Branding & 0.1040 & 0.1078 & 0.0221 & 4.7005 \\
\hline Price->Branding & 0.0230 & 0.0247 & 0.0181 & 2.2723 \\
\hline Image->Branding & 0.2040 & 0.2014 & 0.0262 & 7.7890 \\
\hline
\end{tabular}

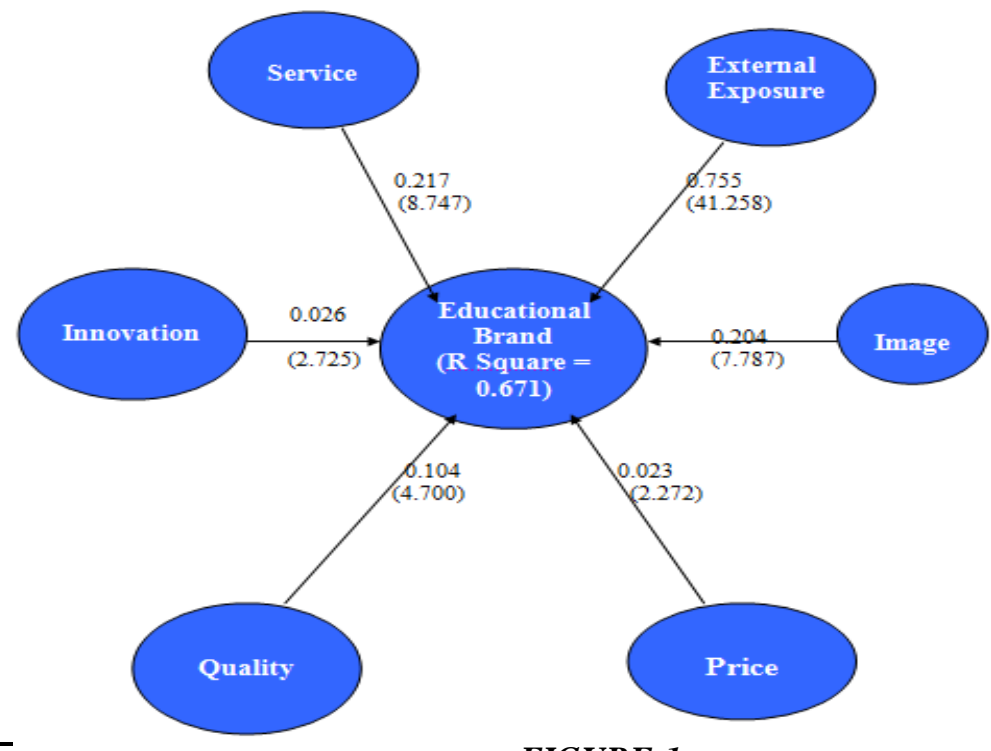

FIGURE:1

A rigorous test of the significance of various proposed relations can be tested using the bootstrap function in Visual PLS. In this method it is possible to use resampling methods (bootstrap and jack knife) to obtain the significance of the various paths in the model. Bootstrap is more reliable in estimating the significance of paths (Chin W W, 1995). So this research has considered and used bootstrap for the purpose of determining causal relations proposed in the model. In general we assume that if the t-statistic is more than 2 , the path is significant.

The above table and figure is the overall effect size measure, as in regression, indicating here that $67.1 \%$ of the variable is explained by the model. Chin (1998: 323; see also Höck \& Ringle, 2006: 15) describes results above the cutoffs $0.67,0.33$ and 0.19 to be "substantial", "moderate" and "weak" respectively. Hence, the R-square here would be considered to be of substantial or significant strength or effect.

$\mathrm{T}$ value of service is 8.747 with beta value 0.217 . Thus, service is influencing in prediction of over all brand rating of the education institution. $\mathrm{T}$ value of innovation is 2.725 and with beta value 0.026 . Thus, innovation is influencing in prediction of over all brand rating of the education institution. T value of Quality is 4.700 with beta value 0.104. Consequently, Quality is influencing in prediction of over all brand rating of the education institution. T value of Price is 2.272 and with beta value 0.023 . Thus, price is influencing in prediction of over all brand rating of the education institution. T value of image is 7.787 and with beta value 0.204 . Hence, image is influencing in prediction of over all brand rating of the education institution. $\mathrm{T}$ value of External Exposure is 41.258 and with beta value 0.755. Thus, External Exposure is influencing in prediction of over all brand rating of the education institution.

\section{Implications}

Multiple regression is computed to find out the influence of branding dimensions on Branding and reveals the fact that with more than eighty nine percent of variance exists in the influence of dimensions of 
educational brand, it corroborates the fact that the model analysed is highly accurate for implementation. Among all the dimensions of educational Brand, external exposure has got significant influence towards branding. It reveals the fact that if there is an increase of one value in external exposure, the brand value of the institution will be increased by .880 . The same way if there is an increase in Price by one value it will leads to .223 increase in the brand value of the institution. Likewise one value increase in service will paves way for .184 increase in the brand value of the institution. Similarly increase of one value in image creates an increase of .162 in the brand value of the institution. It also reveals the fact that increase of one value in quality and innovation will leads to increase of .077 and .043 in the brand value of the institution respectively.

Partial least squares is computed to test the significance of various proposed relations Branding and branding dimensions. It reveals the fact that with more than sixty seven percent of variance exists in the influence of dimensions of educational brand, it indicates the fact that the dimensions such as service, innovation, quality, price, image and external exposure has high impact on Branding of higher educational institutions. The T statistic for all the dimensions of educational branding is greater than two and hence all the paths of dimensions are significant. The beta values for all the dimensions are found to be highly positively significant. This proves our presumption that the dimensions such as Service, innovation, quality, price, image and external exposure has a constructive influence on the branding of higher educational institutions. Both the Multiple regression and Partial Least Squares computation reveals the staunch fact that external exposure dimension has got high influence towards branding of higher educational institution. Thus the higher educational institutions should intensely focus on the external exposure factor as it highly influences the branding of the higher educational institution.

\subsection{CONCLUSION}

Higher education is becoming a global business and is facing the reality of a worldwide competition (Lewis, 2003). Higher Educational Institutions are increasingly turning to branding as way to create an identity and to have a sustained competitive advantage (Montgomery, 2005).

From the study we understand students select their higher educational institutions based on six factors namely service, external exposure, image, price, quality and innovation. From the help of literature review we understand that these are components of branding. Hence the higher educational institutions who are planning to attract quality students should concentrate on the six parameters. So that the brand value of the institution will be increased, no higher educational institutions will survive in the future if they fail to brand their institution in the right way. Higher educational institutions have to brand their institutions before others brand. .

\section{References}

[1]. Aaker, D.A. And Joachimsthaler, E. (2000),Brand Leadership, The Free Press, New York, Ny.

[2]. Aaker, David A. (2004a), Brand Portfolio Strategy. Creating Relevance, Differentiation, Energy, Leverage And Clarity. New York, Free Press.

[3]. Aaker, David A. (2004b), "Leveraging The Corporate Brand" California Management Review, 46 (3), 6-18.

[4]. Aaker, David A. And Erich Joachimsthaler (2000), Brand Leadership, London, Free Press.

[5]. Aaker, Jennifer L. (1997), "Dimensions Of Brand Personality”, Journal Of Marketing Research, 34 (August), $347-356$.

[6]. Alok Chakrabarti, Higher Education And Research In India: An Overview, Sitra Reports, 2007.

[7]. Anderson, J.C. And Narus, J.A. (2004), Business Market Management: Understanding, Creating, And Delivering Value, Pearson Prentice-Hall, Englewood Cliffs, Nj, P. 136.

[8]. Annual Report : 2007-2008, Department Of School Education And Literacy \& Department Of Higher Education, Ministry Of Human Resource Development, Government Of India

[9]. Bob Toper, Vol Xv,No.2, "Branding Higher Education", Marketing Higher Education

[10]. Chen, Arthur C.H. (2001), "Using Free Association To Examine The Relationship Between Characteristics Of Brand Associations And Brand Equity", Journal Of Product And Brand Management, 10 (7), 439-451.

[11]. Chin, W. W. (1998). The Partial Least Squares Approach For Structural Equation Modeling. Pp. 295-336 In G. A. Macoulides, Ed. Modern Methods For Business Research. Mahwah, Nj: Lawrence Erlbaum Associates.

[12]. Chris Chapleo (University Of Portsmouth, Uk) August 17, 2006 Do Universities Have "Successful Brands? International Journal For Educational Advancement

[13]. Cyrus Rohani (2008), "Early Childhood Education”, Eabr \& Tlc Conferences Proceedings, Tlc, Ruthernberg.

[14]. Davis, Scott M. (2002), Brand Asset Management: Driving Profitable Growth Through Your Brands, San Francisco, Josey Bass.

[15]. Elizabeth Scarborough, "The Branding Of Higher Education: The Great Awakening In The Hallowed Halls Of Academia", Intelligent Marketing For Higher Education, May 2007

[16]. Farquhar, Peter H. (1989), "Managing Brand Equity”, Marketing Research, 1 (September), 24-33.

[17]. Farquhar, Peter H., J. Y. Han, And Y. Iriji (1991), Recognizing And Measuring Brand Assets, Report 91-119, Marketing Science Institute, Cambridge, Ma.

[18]. Fournier, Susan (1998), “Consumers And Their Brands: Developing Relationship Theory In Consumer Research", Journal Of Consumer Research, 24 (March), 343-373.

[19]. Geoffrey N.Soutar, Julia P Turner, Students` Preferences For University A Conjoint Analysis, The International Journal Of Educational Management, 40 - 45, 2002

[20]. Gobé, Marc (2001), Emotional Branding: The New Paradigm For Connecting Brands To People, New York, Allworth Press.

[21]. Gobé, Marc (2002), Citizen Brand: 10 Commandments For Transforming Brand Culture In A Consumer Democracy, New York, Allworth Press.

[22]. Hague P. And Jackson, P. (1994), The Power Of Industrial Brands, Mcgraw-Hill, London. 